\title{
How Sensitive Are Bank Managers to Shareholder Value?
}

\author{
Selçuk Caner · Süheyla Özyıldırım • A. Ece Ungan
}

Received: 7 November 2008 / Revised: 1 September 2011 / Accepted: 7 September 2011 /

Published online: 26 October 2011

(C) Springer Science+Business Media, LLC 2011

\begin{abstract}
We test for the existence of market discipline by shareholders of banks with a wide range of ownership structures. Discipline by shareholders manifests itself through monitoring banks' level of risk as well as through influencing banks' management actions. We find that shareholders utilize the relation between stock returns and different types of risk measures to monitor risky banks. Shareholders partially influence bank management by responding to decreasing stock returns with a demand to improve loan quality. Moreover, the influence on management in small banks is more pronounced compared to large banks.
\end{abstract}

Keywords Market discipline - Stock returns • Bank monitoring • Shareholder influence

JEL Classification $\mathrm{G} 20 \cdot \mathrm{G} 21$

We would like to thank Haluk Ünal (the Editor) and the anonymous referee for their useful comments and suggestions.

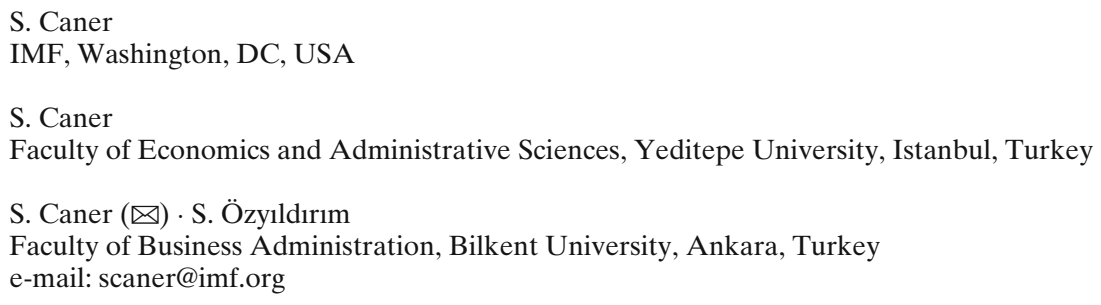




\section{Introduction}

The literature on the market discipline of banks emphasizes the significance of monitoring and controlling for bank risk by private at-risk claimholders (Lane 1993; Flannery 1998, 2001; Bliss and Flannery 2002). Market prices of tradable securities issued by banks provide information that reflect the banks' risks (Flannery and Sorescu 1996; Hancock and Kwast 2001; Morgan and Stiroh 2001). Market prices of these securities also affect the cost of capital and encourage prudent management of bank risks. Market prices of debt, especially subordinated debt, and equity issued by banks are considered two main indicators of monitoring and control (Flannery and Sorescu 1996).

Many bank regulation proposals suggest that debt market signals might be preferable to equity market signals (see, for example, BIS 2003). Compared to shareholders, debtholders and bank supervisors are concerned more about the downside risks that affect a bank's performance than the upside potential (Furlong and Williams 2006). However, tests of market discipline on the relation between debt and bank risks are inconclusive (Goyal 2005). Sunderesan (2001), Kwan (2002), and Flannery et al. (2004) argue that equity market signals are superior to debt market signals in terms of depth and informational efficiency.

In this paper, we test the market discipline of banks in terms of the relation between market signals and banks' risk-taking behavior using sample of Turkish banks. We use banks stock prices (returns) to assess the ability of shareholders to control the risk taking by bank management. More precisely, we test whether market indicators related to banks' risk factors and obtained from financial statements provide sufficient influence on management's behavior. We also show that shareholders' monitoring and influence on management differ between small and large banks. Small banks are owned by one dominant shareholder and a group of small investors while ownership of large banks is more heterogeneous. Large banks are owned by few large shareholders and many small investors. The large owners are often another bank, a large industrial firm, or a mutual fund.

We observe that banks with concentrated ownership experience more monitoring and control over management by shareholders. When a public firm's ownership is concentrated in the hands of a few large shareholders, these shareholders have both the incentive and the power to monitor and influence the firm's management. Shleifer and Vishny $(1986,1997)$ argue that large shareholders have the incentive to collect information and monitor management for the purposes of profit maximization. Demsetz and Lehn (1985) and Himmelberg et al. (1999) emphasize that if large shareholders are inactive then the resulting costs are borne by the same shareholders. The downside potential of not monitoring is high, especially high for leveraged firms like banks, saving and loans institutions, insurance companies, and securities firms. In two other studies, Demsetz $(1983,1986)$ claims that a shareholder's ability to exercise oversight and control "must be the primary explanation for ownership concentration." For example, at the Mellon Bank in 1987, the Mellon family's change of management, with less than 50\% ownership, represents a good case for the influence of concentrated ownership on management (Haubrich and Thomson 1998).

Management's response to a decline in banks stock prices is muted and exists only in small banks. Further analysis also suggests that a pecking order might exist in the management's response. Management's response to negative returns is to 
reduce nonperforming loans, increase liquidity, and increase capital. So, in a way management uses the most readily available measures first, then considers other time consuming and costly measures. Large banks have highly sophisticated instruments in their balance sheets, thus it might not be possible for shareholders to assess the riskiness of various assets. Therefore, no matter how large the ownership share, investors might be unable to control management given the proportion of complex and opaque financial instruments relative to the size of the bank. Flannery et al. (2004) show that market investors have good information about smaller banks (listed on Nasdaq) compared with size-matched firms. Their findings suggest that bank stock-price data are at least as good, and in the case of smaller banking firms, perhaps even better than those of nonfinancial firms at reflecting firm-specific information. Shareholders' influence on risk taking declines as bank size increases. Moreover, they show that the introduction of bank regulatory and deposit insurance agencies are only effective in improving the capital adequacy ratio of small banks.

We use data on the Turkish banking industry to test for the existence of market discipline. With its developed banks and the majority of them traded on the stock exchange, the Turkish banking industry provides a good test of market discipline by shareholders. The existence of concentrated ownership (family blockholders and large shareholders) in the majority of the publicly traded banks in Turkey and weak shareholder protection laws (Hacimahmutoglu 2007) provide a sufficiently testable environment for observing shareholders' influence on management.

Moreover, Turkey has some interesting bank ownership structures; financial returns do not motivate all the shareholders of these banks. For example, a political party is a large shareholder in one of the largest private banks. ${ }^{1}$ In another case, government is the largest shareholder in a publicly traded bank. Employees' pension funds also own significant shares in banks, motivated by job security and benefits to employees. In such a diverse ownership structure, the evidence shows that shareholders are differentiated by their sensitivity to negative stock returns and different measures of risk. In addition, the relationship between management and shareholder can be different in small banks than in large banks.

The remainder of the paper is organized as follows: Section 2 provides a brief summary of the related literature on market discipline. Section 3 discusses the model and the data used by shareholders in monitoring and influencing banks. We interpret the estimation results in Section 4. The paper concludes with Section 5.

\section{Literature review}

Lane (1993) defines market discipline in the context of financial markets as "providing signals that lead borrowers (i.e., banks) to behave in a manner consistent with their solvency." This definition leads to the two components of market discipline defined by Bliss and Flannery (2002): "Monitoring" refers to market participants'

\footnotetext{
${ }^{1}$ A political party that is regarded as social-democratic and is a member of the Socialist International, the worldwide organization of social-democratic, socialist, and labor parties owns $28.1 \%$ of İşbank. In the empirical analysis, we exclude banks that might have shareholders with different motivations than stock value maximization as a robustness check of our findings.
} 
incentives and ability to understand changes in a firm's condition and incorporate their opinions into the firm's stock and debt prices. "Influence" refers to the process by which the changes in market participants' behaviors induce the managers to respond to adverse changes in the banks' financial conditions.

A large volume of literature exists on the different forms of market discipline on banks. Early literature focuses on the effects of subordinated debt and the effectiveness of depositors in limiting risk taking by bank management. However, the literature on the disciplining role of shareholders remains relatively small. Docking et al. (1997) provide evidence that loan-loss-reserve announcements have a significant correlation with the negative returns of U.S. bank shares. Return on equity is sensitive to other factors that indicate an increase in the bank's riskiness. Billet et al. (1998) document evidence that a decline in equity prices after Moody's debt-rating downgrades represent discrete changes in bank risk. They show that Moody's debt-rating downgrades increase future uninsured debt-financing costs of banks and, hence, have a negative effect on equity prices.

Another source for the negative response of market prices is the announcement of supervisory reviews for remedial action in order to avoid failure as shown by Jordan et al. (2000). The release of supervisory information provides significant information to the market resulting in a $5 \%$ decline in stock prices on average. According to Krainer and Lopez (2004), market variables such as equity returns and probabilities of default are useful indicators that supervisors use to assess the soundness of bank holding companies (BHCs). They conclude that equity-based indicators are predictors in BOPEC downgrades and improve the performance of early warning systems. ${ }^{2}$ More recently, Cannata and Quagliariello (2005) examine the behavior of four commonly used equity-based indicators on Italian banks listed on the Milan Stock Exchange between 1995 and 2002: equity prices, daily returns, volatility, and distance to default. They find that equity-based variables confirm supervisory ratings assigned by the Bank of Italy's PATROL ratings that suggest that the use of market signals for bank monitoring are appropriate. ${ }^{3}$ Distinguin et al. (2006) examine downgrade and upgrade events for 64 European banks for the period of 1995-2002 and find that stock market prices, especially the difference between market prices and the 216-day moving average, significantly predict future financial distress for banks. They suggest that stock market prices might be effective in disciplining banks.

While evidence supports close monitoring of bank riskiness by shareholders, the ability of the shareholders to sway bank management from disproportional risk taking is not well established. As argued by Bliss and Flannery (2002), negative market signals might only be suggestions to management to make changes. Examining quarterly excess returns during 1986-1997 for large U.S. BHCs, they find weak evidence of stockholders' influence on managerial actions. Among multiple measures of market signals, such as a number of managerial action variables and various lags between signal and potential action, they find that only increased dividend payments and changes in uninsured liabilities of BHCs are evidence of

\footnotetext{
${ }^{2}$ BOPEC: Bank subsidiaries, Other non-bank subsidiaries, Parent company, Earnings and Capital adequacy.

${ }^{3}$ PATROL: Capital adequacy, Profitability, Credit risk, Management and Liquidity.
} 
influence by stockholders. However, Nier and Baumann (2006) show that banks' disclosures to shareholders limit their default risk by increasing capital ratios, which suggest market influence. Event studies such as managerial terminations also indicate stockholders' influence. For example, Parrinoa et al. (2003) show that stockholders can vote out management and that poor firm performance increases the likelihood of managerial turnover. Cihak et al. (2011) find that executives are more likely to be dismissed if their bank is risky and incurs losses, which suggests discipline from shareholders. Nevertheless, the market discipline paradigm requires timely and accurate assessment of banks' financial conditions. Hence, managerial turnover can be too late for avoiding bank failure.

Other studies consider the possible effectiveness of total risk, portfolio beta, and idiosyncratic risk as informative signals for market participants. For example, Hall et al. (2002) show that shareholders' valuation of credit risk is about the same as the regulators' valuation for BHCs. Moreover, their results indicate that the variables representing interest-rate risk, credit risk, liquidity risk, off-balance sheet risk, and earnings do fairly well in explaining the variance in the market measures of risk. Nikolova (2003), Kwan (2004), Krainer and Lopez (2004) and Gropp et al. (2006) combine equity and debt-market indicators by constructing implied asset volatility estimates of banks and, using either set of indicators, show that the combined indicators outperform the models that explain bank risks. Curry et al. (2008) present evidence that excess returns and the standard deviation of quarterly returns explain BOPEC rating upgrades, hereby establishing the conditions for shareholder discipline to be effective.

While market discipline of banks is documented for developed financial markets, it is not sufficiently studied in emerging markets. Caprio and Honohan (2004) provide evidence from emerging markets that the probability of stock market discipline increases as the listed banks' assets increase as a share of total banking assets. However, they find no evidence for the influencing ability of shareholders on bank management.

\section{The models and the data}

\subsection{Models of shareholder monitoring and influence}

We estimate the responsiveness of shareholders to bank risk and their ability to influence management decisions on bank risk using two empirical models. Bliss and Flannery (2002) define the interaction between shareholders and bank management as market discipline that demonstrates the investors' ability to evaluate the banks' financial condition and the responsiveness of the bank's management to the investors' stock-return assessment.

First, we consider estimating the shareholders' assessment of the riskiness of publicly traded banks based on the banks' financial reports. Stock-price changes are readily available to shareholders; and, with the announcements of the bank financial indicators such as the risk ratios, shareholders react to the news by adjusting their holdings of bank shares. Thus, shareholders' bank-risk monitoring behavior exists if there is a significant relation between equity returns and risk measures obtained from the financial statements of banks. 
Second, we model the shareholders' effectiveness in modifying management risktaking behavior. While positive returns might not necessarily result in any management action, negative returns should prompt bank management to take action to adjust the risk structure of the bank. However, the extent of the influence of shareholders portfolio decisions on managerial actions is not observable. To estimate the extent of the influence of shareholders on bank management, we present a model where negative returns are regressed on the change in the sign of the risk parameters from the balance sheets after controlling for other factors.

Model I: shareholders' bank risk monitoring behavior In the first model, we estimate the shareholders' abilities to monitor bank risks from the financial statement data. Market responses represent shareholders' assessments of bank risk taking, and stock prices signal shareholders to follow the market's valuation of the bank. Banks stock prices and returns fluctuate according to the risks taken by banks after controlling for other bank specific variables and macroeconomic conditions. The monitoring model is as follows:

$$
Y_{i t}=\alpha_{i}+\phi Y_{i t-1}+\sum_{j=1}^{4} \gamma_{j} \text { Bank Risk }_{i j t-1}+\sum_{k=1}^{3} \theta_{k} X_{i k t-1}+\psi Z_{t-1}+e_{i t}
$$

where $Y_{i t}$ is the stock return for bank $i$ at the quarter $t$ and $e_{i t}$ is the error term. The $Y_{t-1}$ is the lagged values of stock returns. We compute the stock returns as the $\log$ difference in the closing price of the stock over the period $t$ and $t-1 .^{4}$ In Eq. 1 , the variable Bank Risk represents the CAMEL ratios obtained from the banks' financial statements: capitalization (Capital/Assets), asset quality (Nonperforming Loans/Assets), managerial performance (Operational Efficiency), and liquidity (Liquid Assets/Asset). ${ }^{5}$ We use efficiency instead of return on asset as a proxy for management performance to avoid any causality problem between stock and asset returns. The efficiency score would be independent of the banks' risk taking because it only shows how resources are allocated. Bank capitalization, liquidity, earnings, and operational efficiency are expected to have a positive relation to equity returns. An increase in the nonperforming loans-to-assets ratio indicates a low return for the bank.

We have two sets of control variables: $X_{i k}$ denotes control variables that are related to other bank characteristics that might affect stock returns. These are leverage ratio (Total Deposits/Assets), franchise value (Market-to-Book), and the trading volume of the banking firm in the capital market (Total Trading Volume (in logs)). The $Z$ is used to control the changes in the macroeconomic conditions. It is represented by the quarterly changes in the current gross domestic product (GDP

\footnotetext{
${ }^{4} \mathrm{We}$ also estimate the model using excess returns. Excess returns are calculated by taking the difference between the stock return of a bank at the closing date and the quarterly average overnight lending rate. Because our results are robust with excess returns, we only report the findings with raw returns. Estimations with excess returns can be provided on request.

${ }^{5}$ Operational efficiency scores are calculated using a Cobb-Douglas frontier (Batesse and Coelli 1995). The estimated scores show the efficiency in providing loans for given deposits and the labor force.
} 
Growth), and it is hypothesized that an increase in gross domestic product increases stock returns.

Model II: shareholders' influence on management Shareholders expect management action to correct disproportionate risk taking. Shareholders' influence on bank management exists if rational managers become aware of declining stock prices and take action to mitigate the increase in bank-risk factors. Therefore, in the influence model, bank risk is expected to decrease in the periods following negative stock returns defined by one of the three risk indicators; namely, increases in the capital-toasset ratio $(\Delta(K / A)>0)$, liquid assets-to-asset ratio $(\Delta(L / A)>0)$, or a decrease in the nonperforming loans-to-assets ratio $(\triangle(N P L / A)<0) .{ }^{6}$ We hypothesize that the impact of stock returns on managerial risk-taking behavior is asymmetric. We assume that only negative market signals indicate that investors might want management to make changes, whereas positive signals generally do not suggest that change is desired. Hence, it is expected that managers might respond to improve their banks' capitalization, liquidity, and asset quality when stock returns decline. ${ }^{7}$

To estimate the extent of shareholders' influence on decisions about the composition of the balance sheet by bank management, we model the effect of the marketprice indicators on the change in bank-risk factors by using the following logit model:

$$
\text { Influence }_{i t}=\alpha_{i}+\phi Y_{i t-1}+\sum_{k=1}^{2} \theta_{j} \mathrm{X}_{i k t}+\psi Z_{t}+e_{i t}
$$

where $e_{i t}$ is the error term. The Influence ${ }_{i t}$ is a binary variable that equals one if bank $i$ decreases its risk (i.e., reduces its nonperforming loans-to-assets ratio or increases its capital-to assets and liquid assets-to-assets ratios) and zero if bank $i$ increases its risk (i.e., increases its nonperforming loans-to-assets ratio or decreases its capital-toassets ratio and its liquid assets-to-asset ratio). The Influence $_{i t}$ measures whether expected management action is taken or not. The $Y_{i t-1}$ denotes negative stock returns for bank $i$ at quarter $t-1$. We hypothesize that negative stock returns contain components that can be avoided by managerial decisions. Hence, negative stock returns increase the probability of managers' responses, and their decisions should result in decreases in the bank's specific risks or in decreases in moral hazard (Demsetz et al 1996; Keeley 2000). Since, the sample in the influence model is limited to those quarters where lagged stock return was negative the number of observations in the empirical analysis of influence model will be smaller relative to monitoring model (see Table 3).

In Eq. 2, control variables $\left(X_{i k}\right)$ are bank size (Assets (in logs)) and franchise value (Market-to-Book). Although we have no a priori expectation about the relation between the variable Influence it $_{\text {in }}$ and the size of the bank, increases in bank-franchise value are expected to reduce moral hazard. The $Z$ denotes a dummy variable (BRSA Dummy) to control the changes in bank management in Turkey after

\footnotetext{
${ }^{6} \Delta$ denotes change per unit of time.

${ }^{7} \mathrm{~A}$ similar approach on the effect of shareholder influence is also provided by Bliss and Flannery (2002) where equity returns prompt managerial action to increase the market value of the bank.
} 
the introduction of the newly established banking regulatory agency, the Banking Regulation and Supervision Agency (BRSA). BRSA Dummy takes a value of zero from the beginning of the estimation period until the fourth quarter of 2000 and a value of one starting in the fourth quarter of 2000 until the third quarter of $2006 .^{8}$

\subsection{Data}

We use quarterly data over the period of 1997:4-2006:3. Financial statements for each publicly traded bank come from the Banking Association of Turkey. The number of sample banks varies due to closures and acquisitions. In 1997, there were 12 publicly traded deposit banks in the dataset. During the sample period, shares of five new banks started trading on the Istanbul Stock Exchange (ISE) and four banks were closed by the State Deposit Insurance Fund (SDIF). ${ }^{9}$ Once a bank is taken over by the SDIF, shares of that bank are no longer traded on the ISE. ${ }^{10}$ Therefore, the dataset is an unbalanced panel of 10 to 16 banks. All bank data from financial statements are transformed into dollars because of the high depreciation in the value of the Turkish Lira until 2005. The banks included in the dataset account for about $65 \%$ of the assets of the banking industry.

Macroeconomic data come from the Central Bank of the Republic of Turkey. Daily bank equity prices and the ISE 100 Index come from DataStream. All stock price data are adjusted for rights' offerings, stock splits, and dividend payments.

In Table 1, we provide trading and ownership data of the banks included in the dataset. In addition, we include initial public offering dates, type of management, and the date of change in management. During the time period studied, large shareholders remained active in the management of banks until 2005. Since then, many banks in the Turkish banking industry have undergone a change in ownership and management because foreign ownership has increased. By the end of 2006, seven publicly traded banks out of 16 were managed by professional management teams. The banking system consists of five large banks with relatively heterogeneous ownership and the remaining small banks with concentrated ownership. The average size of the large banks over the sample period is $\$ 11.7$ billion while the average size of small banks is $\$ 1.5$ billion.

In Table 2, we present the summary statistics of all variables that are used in the monitoring and influencing models. During the sample period of 1997:4 to 2006:3,

\footnotetext{
${ }^{8}$ Until June 23, 1999, the Treasury Undersecretariat and the Central Bank of Republic of Turkey had been the two main regulatory and supervisory bodies in the banking sector in Turkey. Since then, the Banking Regulation and Supervision Agency, with financial and administrative autonomy, exercises its supervisory authority on a direct and ongoing basis in terms of legal considerations and financial soundness. All banks' financial statements are audited by external auditors in accordance with internationally accepted principles of accounting. See Steinherr et al. (2004) for a review of banking supervision in Turkey.

${ }^{9}$ The Savings Deposit Insurance Fund (SDIF) was established in 1983 to insure savings deposits in banks. Initially, SDIF was administrated by the Central Bank of Turkey. In 1994, the Fund's duties were expanded and the SDIF was charged in strengthening and restructuring the financial condition of banks when necessary. Since 2000, SDIF has being administered and represented by BRSA.

${ }^{10}$ SDIF took control of four banks between December 1999 and November 2001.
} 


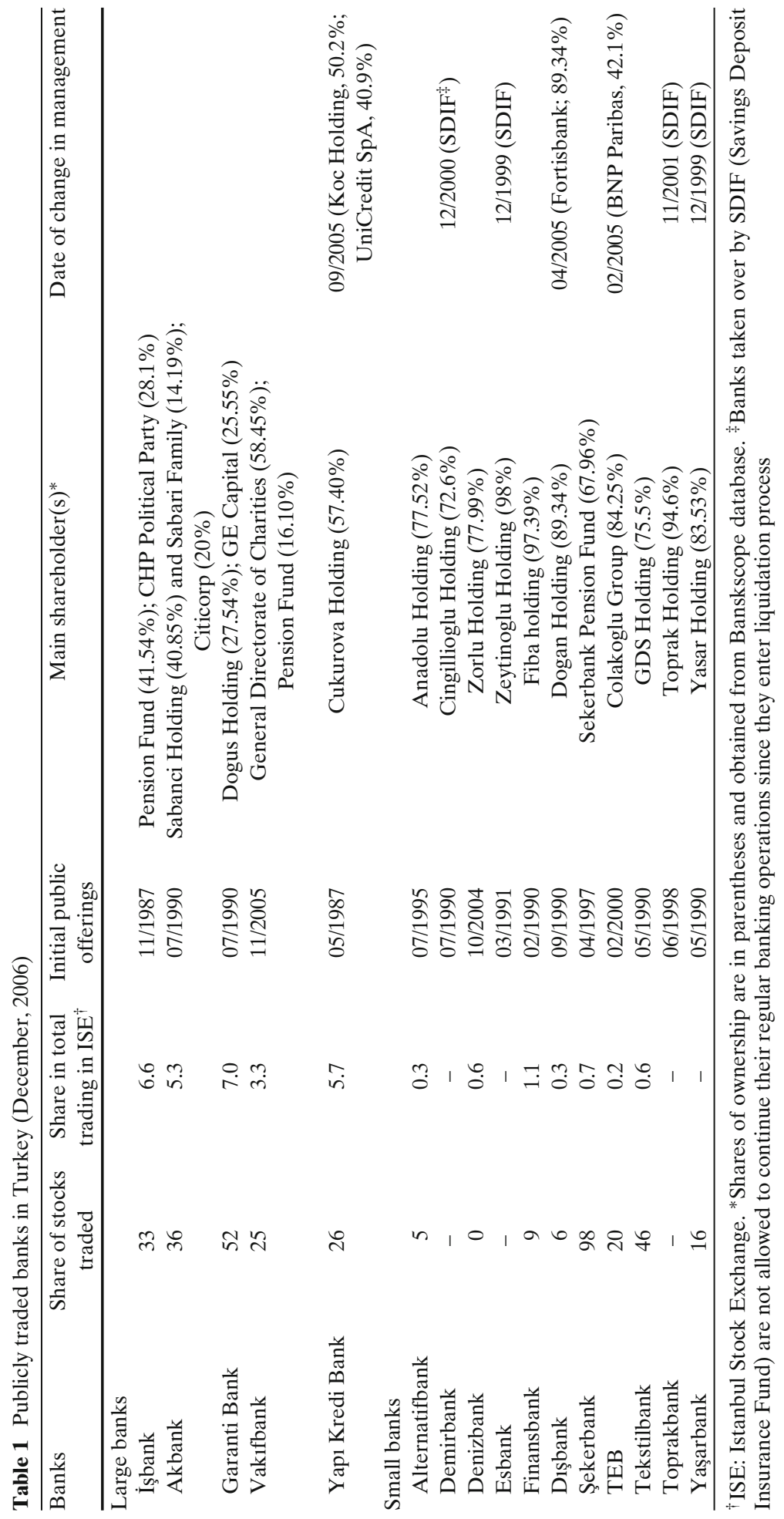




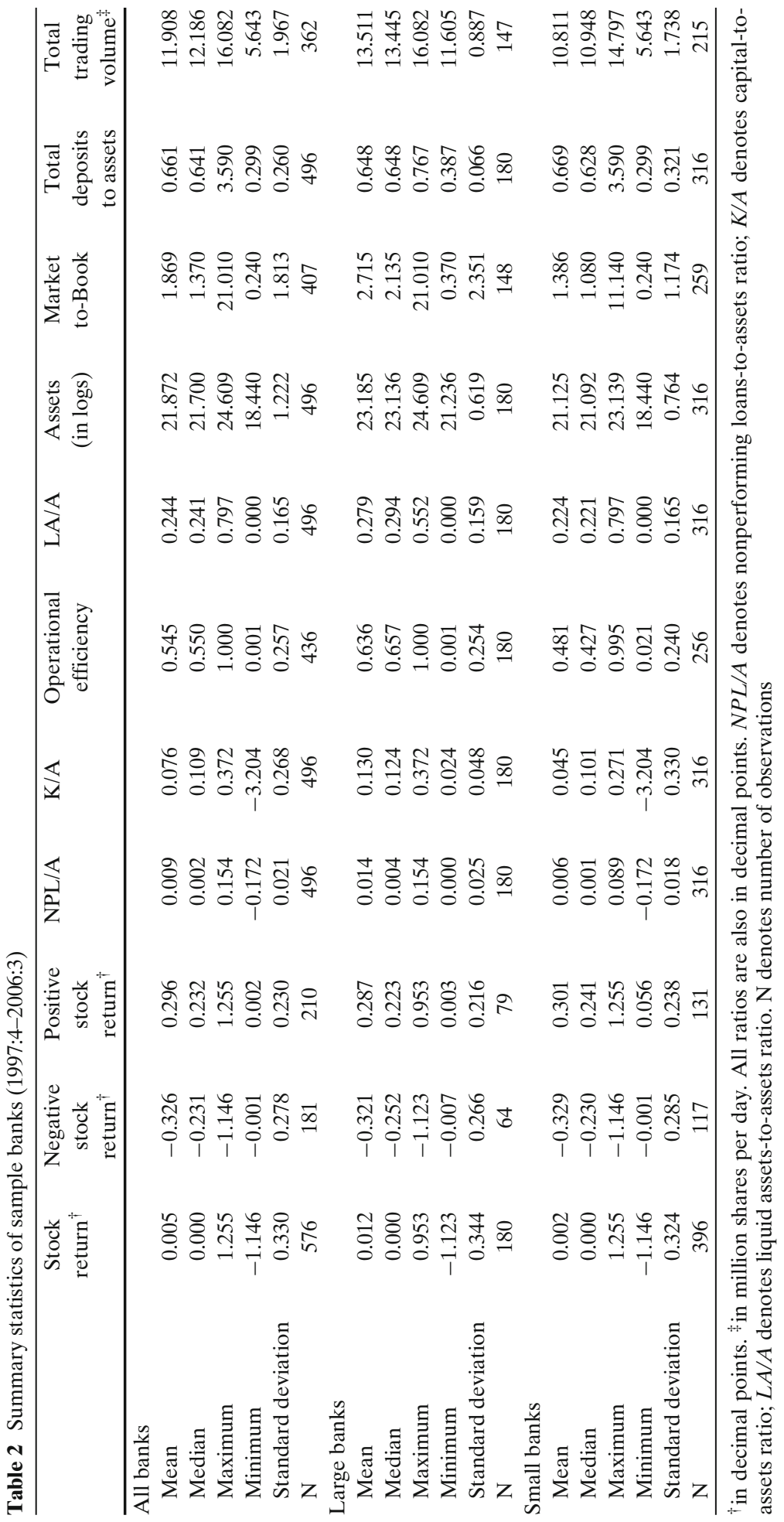


Table 3 Distribution of the sign of influence variables

${ }^{\dagger}$ Total number of observations is different due to use of lagged values

\begin{tabular}{lccc}
\hline & \multicolumn{2}{c}{ Stock return $\left(Y_{t-1}\right)$} & $\mathrm{N}$ \\
\cline { 2 - 3 } & Positive $\left(Y^{+}\right)$ & Negative $\left(Y^{-}\right)$ & \\
\hline$\Delta(K / A)>0$ & 91 & 89 & 180 \\
$\Delta(K / A)<0$ & 102 & 77 & 179 \\
$\mathrm{~N}^{\dagger}$ & 193 & 166 & 359 \\
$\Delta(L A / A)>0$ & 91 & 108 & 199 \\
$\Delta(L A / A)<0$ & 109 & 71 & 180 \\
$\mathrm{~N}$ & 200 & 179 & 379 \\
$\Delta(N P L / A)<0$ & 143 & 128 & 271 \\
$\Delta(N P L / A)>0$ & 57 & 51 & 108 \\
$\mathrm{~N}$ & 200 & 179 & 379 \\
\hline
\end{tabular}

average daily stock returns per quarters are $0.5 \%$ for all banks, almost zero for small banks and $1.2 \%$ for large banks. Moreover, quarterly log values of returns are highly volatile for the full sample and subsamples of large and small banks. For all banks, the average quarterly negative (positive) returns are 32.6 (29.6) percent with standard deviations of 27.8 (23.0) percent.

Significant variation exists among banks. In terms of bank characteristics, small banks are less well capitalized compared to large banks but have less nonperforming loans. The profitability of small banks is on average below zero during the sample period. Large banks' capital ratios are above the minimum required level yet they are highly profitable. The calculated average score for operational efficiency at 0.545 is low compared to U.S. and European banks. ${ }^{11}$ However, efficiency scores have improved over time.

The liquidity of large banks is, on average, five percentage points higher than for small banks during the sample period. This difference might be interpreted as evidence of why small banks must be monitored more closely than large banks. While small banks have more funding from depositors as compared to large banks, their deposits-to-asset ratio varies significantly with a standard deviation almost five times (6.6\% for large banks versus $32.1 \%$ for small banks) the standard deviation of large banks. In terms of total trading volume, trading of small banks shares is highly active and close to the trading levels of large banks shares.

Table 3 summarizes the quarterly movements of stock returns and possible managerial actions that the influence model hypothesizes. More precisely, we report positive/negative influence (change in capital-to-asset, liquid assets-to-assets, and nonperforming loans-to-assets ratios) and lagged stock-return sign counts. For example, there are 89 (77) observations of increases (decreases) in the capital ratio following a negative quarterly stock return. Liquid assets increase (decrease) in 108 (71) out of 179 quarters following a negative return. Following a negative quarterly stock return in 128 out of 179 quarters, banks reduce their nonperforming loans. In the next section, we present the robust relation between negative stock returns and risk reducing managerial actions that results in decreasing nonperforming loans.

\footnotetext{
${ }^{11}$ For example, see Casu and Molyneux (2003) on European Union banks and Berger and Mester (1997) on U.S. banks.
} 


\section{Estimation results}

In Tables 4, 5, and 6, we present the results from using the bank monitoring and influence models. First, we examine the monitoring behavior of shareholders by using returns on bank stocks. Financial ratios such as nonperforming loans to total assets, capital-to-total assets, liquid assets to total assets, and operational efficiency are used to determine the existence and effectiveness of shareholder monitoring. Shareholders follow these ratios to assess the riskiness of their investments. Changes in these risk indicators can affect the rate of return to shareholders. This relation is also examined for subsamples of small and large banks. There is a difference in the ownership structure between large and small banks. As discussed before, large banks in Turkey are owned by a few large shareholders; such as, a foreign bank, an industrial holding company or another institution, plus a large number of small shareholders. Ownership in small banks is more concentrated, with more than two-thirds of the shares owned by one large industrial holding company and the remainder by small investors. ${ }^{12}$

Second, we present evidence on the influence of the shareholders on management that results in adjustments to bank-risk indicators. Shareholder influence depends on the existence of a relation between the financial ratios and adverse stock returns. This relation is also examined for small and large banks to understand how influence might differ by type of bank.

\subsection{Monitoring}

We test for the existence of monitoring by shareholders by regressing bank-risk variables on stock returns. Bank-risk variables obtained from the financial statements of banks, bank-specific control variables, and an indicator of general economic conditions are regressed on stock returns. Table 4 presents the fixed-effect estimation results of the monitoring model described in Eq. 1. The same monitoring model is regressed for subsamples of large and small publicly traded banks as well as for all banks.

As seen in Table 4, banks' operational efficiency and liquidity are the two significant risk indicators monitored by shareholders for all banks. Moreover, the reduction in the liquidity risk or risk of not having sufficient cash or borrowing capacity to meet deposit withdrawals increases significantly the stock returns of both small and large banks. However, efficiency is only significant for small banks. As presented in Table 2, small banks are, on average, less efficient than large banks. Because managerial inefficiency can typically reflect the excessive use of or payment for branches, labor, or the excessive deposit interest cost, the cost of reorganizing a bank even a small scale bank can be very high. Similar to the finding by Wheelock and Wilson (2000) for U.S. banks, our findings suggest that a small bank that can control its cost or improve efficiency signals vigilant management. Capital ratio and nonperforming loans have the predicted sign but are insignificant for the full sample of banks as well as both subsamples. For small banks, the coefficient for nonperforming loans has the wrong sign but is not significant. These results indicate

${ }^{12}$ Three of the small banks have foreign majority shareholders as of 2005 (Table 2). 
Table 4 This table presents fixed effect estimates of the monitoring model for the the period of 1997:4 and 2006:3:

$$
Y_{i t}=\alpha_{i}+\phi Y_{i t-1}+\sum_{j=1}^{4} \gamma_{j} \text { Bank Risk } k_{i j t-1}+\sum_{k=1}^{3} \theta_{k} X_{i k t-1}+\psi Z_{t-1}+e_{i t}
$$

where $Y_{i t}$ denotes stock return from quarter $t-1$ to $t$ for bank $i$. Bank Risk $k_{i t-1}$ denotes lagged values of nonperforming loans-to-assets, capital-to-assets, operational efficiency, and liquid assets-to-assets. $X_{i t-1}$ denotes lagged values of three bank specific control variables for bank $i$ : Total Deposits-toAssets, Trading Volume and Market-to-Book value of the bank. $Z_{t-1}$ denotes macroeconomic control variable: lagged values of GDP growth. t-statistics are in parentheses

\begin{tabular}{|c|c|c|c|}
\hline & All & Small & Large \\
\hline Stock return $_{t-1}$ & $\begin{array}{c}-0.401 * * * \\
(-7.881)\end{array}$ & $\begin{array}{c}-0.421 * * * \\
(-6.322)\end{array}$ & $\begin{array}{l}-0.400 \text { *** } \\
(-4.858)\end{array}$ \\
\hline \multicolumn{4}{|l|}{ Bank risk variables $_{t-1}$} \\
\hline Nonperforming loans/assets & $\begin{array}{c}-0.473 \\
(-0.384)\end{array}$ & $\begin{array}{c}4.517 \\
(1.221)\end{array}$ & $\begin{array}{c}-1.856 \\
(-1.427)\end{array}$ \\
\hline Capital/assets & $\begin{array}{c}0.919 \\
(1.287)\end{array}$ & $\begin{array}{c}0.876 \\
(0.711)\end{array}$ & $\begin{array}{c}1.565 \\
(1.580)\end{array}$ \\
\hline Operational efficiency & $\begin{array}{c}0.343 * * * \\
(4.161)\end{array}$ & $\begin{array}{c}0.467 * * * \\
(3.872)\end{array}$ & $\begin{array}{c}0.187 \\
(1.540)\end{array}$ \\
\hline Liquid assets/assets & $\begin{array}{c}1.060 * * * \\
(6.771)\end{array}$ & $\begin{array}{c}1.012 * * * \\
(4.363)\end{array}$ & $\begin{array}{c}1.269^{* * * *} \\
(5.372)\end{array}$ \\
\hline \multicolumn{4}{|l|}{ Control variables $\left(X_{i t-1}\right)$} \\
\hline Total deposits/assets & $\begin{array}{l}0.519 * \\
(1.913)\end{array}$ & $\begin{array}{c}0.352 \\
(0.975)\end{array}$ & $\begin{array}{c}0.827 \\
(1.327)\end{array}$ \\
\hline Total trading volume (in logs) & $\begin{array}{c}0.080 * * * \\
(4.403)\end{array}$ & $\begin{array}{c}0.083 * * * \\
(3.696)\end{array}$ & $\begin{array}{l}0.143^{* * *} \\
(3.127)\end{array}$ \\
\hline Market-to-Book & $\begin{array}{c}0.098^{* * *} \\
(6.226)\end{array}$ & $\begin{array}{c}0.123 * * * \\
(4.288)\end{array}$ & $\begin{array}{c}0.091 * * * \\
(4.173)\end{array}$ \\
\hline \multicolumn{4}{|l|}{ Macroeconomic variable $\left(Z_{t-1}\right)$} \\
\hline GDP growth & $\begin{array}{c}-2.161 * * * \\
(-6.163)\end{array}$ & $\begin{array}{c}-2.171 * * * \\
(-4.674)\end{array}$ & $\begin{array}{c}-2.309 * * * \\
(-3.893)\end{array}$ \\
\hline Adj. R-squared & 0.295 & 0.290 & 0.316 \\
\hline F statistics & 20.833 & 12.514 & 9.808 \\
\hline Prob $>$ F & 0.000 & 0.000 & 0.000 \\
\hline Number of observations & 352 & 209 & 143 \\
\hline
\end{tabular}

***,** and * denote statistical significance at the $1 \%, 5 \%$, and $10 \%$ levels, respectively

that share prices as market variables respond to changes in some, but not all, bankrisk indicators. Among the control variables, trade volume and market-to-book value have positive and significant impacts on stock returns as expected.

\subsection{Influence}

As emphasized by Bliss and Flannery (2002), shareholders must be able to influence banks' risk-taking behavior in order to exercise market discipline. However, shareholders might prefer a riskier investment strategy as long as the expected return compensates them for the additional risk. Hence, their incentives to discipline banks are not as obvious as other security holders such as bondholders. Nevertheless, due to the increasing complexity of banking activities and the inability of supervisors to monitor and control them using standard risk measures; shareholders, especially major shareholders, seem to be the natural candidates for effective market discipline. 
Table 5 The effect of market price indicator on the change in bank-risk factors is using the following logit model (influence model):

$$
\text { Influence }_{i t}=\alpha_{i}+\phi Y_{i, t-1}+\sum_{j=1}^{2} \theta_{j} \mathrm{X}_{i j t}+\psi Z_{t}+e_{i t} .
$$

Influence $_{i t}$ is one if quarterly changes in capital-to-assets, and quarterly changes in liquid assets-to-assets ratios are positive. Also, In fluence $e_{i t}$ is one if quarterly changes in nonperforming loans-to-assets ratio is negative. Otherwise, Influence $i t$ is zero. $Y_{i t-1}$ denotes lagged values of negative stock returns for bank $i$. $X_{i t}$ denotes the two bank specific control variables: bank size (Assets (in logs)) and franchise value of the bank (Market-to-Book). $Z_{t}$ denotes the dummy variable (BRSA Dummy) to identify the periods with new independent regulatory and supervisory agency for banking in Turkey. Notes: $\Delta$ denotes change over time. $K / A$ is capital-to-asset $\operatorname{ratio}, L A / A$ is liquid asset-to-asset ratio and $N P L / A$ is non-performing loans-to-asset ratio. z-values are in parentheses

\begin{tabular}{lcccc}
\hline & \multicolumn{3}{c}{ Influence $_{\text {it }}=1$ when } \\
\cline { 2 - 3 } & \multicolumn{2}{c}{ Increase } & Decrease \\
\cline { 2 - 3 } & $\begin{array}{c}\text { Capital/assets } \\
(\Delta(K / A)>0)\end{array}$ & $\begin{array}{c}\text { Liquid assets/assets } \\
(\Delta(L A / A)>0)\end{array}$ & $\begin{array}{c}\text { Nonperforming loans/assets } \\
(\Delta(N P L / A)<0)\end{array}$ \\
\hline Stock return ${ }_{t-1}$ & 0.097 & -0.249 & $1.627^{* * *}$ \\
Control variables $\left(X_{i t}, Z_{t}\right)$ & $(0.164)$ & $(-0.437)$ & $(2.690)$ \\
Assets (in logs) & & & \\
& $-0.038^{*}$ & $0.039^{* *}$ & $0.103^{* * *}$ \\
Market-to-Book & $(-1.881)$ & $(2.121)$ & $(4.711)$ \\
& $0.393^{* * *}$ & -0.146 & $-0.248^{*}$ \\
BRSA dummy & $(2.575)$ & $(-1.158)$ & $(-1.829)$ \\
Log likelihood & $0.638^{*}$ & -0.516 & -0.611 \\
N with Dependent Variable $=0$ & $(1.752)$ & $(-1.497)$ & $(-1.564)$ \\
N with Dependent Variable $=1$ & -110.40 & -118.47 & -100.35 \\
\hline
\end{tabular}

$* * *, * *$ and $*$ denote statistical significance at the $1 \%, 5 \%$, and $10 \%$ levels, respectively

To test for the existence of influence by shareholders on management, we use logistic regressions. Any evidence of influence on management would manifest itself in changes in key financial ratios in response to share prices or returns. While it is possible to have a long list of management action that includes asset sales, workforce reduction etc., we limit our estimates to three key risk indicators where the dependent variables are the probability of a change in the capital adequacy ratio, the liquidity ratio, and the nonperforming loans-to-asset ratio. These are the most commonly used policy actions by management within a short period of time in response to lower returns to shareholders. In particular, the effect of negative stock returns, and their association with increasing risk indicators, would compel management to take action. We control for other factors such as size, franchise value, and the effect of bank regulation in the influence model as described in Eq. 2.

The estimated equations of influence are reported in Table 5. After controlling for other factors, we find a significant relation between stock returns and nonperforming loans. The coefficient of stock returns is significant at the $1 \%$ level. The coefficients of capital asset and liquidity equations are not significant. Because it is costly to increase capital, management does not consider increasing the capital ratio as a measure to reduce risk. So, the response of managers to negative stock returns seems to be ineffective on improving the bank's capitalization. 
Table 6 Influence model estimates for small versus large banks. z-values are in parentheses

\begin{tabular}{|c|c|c|}
\hline & Small banks & Large banks \\
\hline \multicolumn{3}{|l|}{ Dependent variable: $\Delta(K / A)>0$} \\
\hline Stock return $t_{t-1}$ & $\begin{array}{c}-0.295 \\
(-0.363)\end{array}$ & $\begin{array}{c}0.953 \\
(0.964)\end{array}$ \\
\hline Log likelihood & -62.12 & -41.81 \\
\hline $\mathrm{N}$ with Dependent Variable $=0$ & 51 & 26 \\
\hline $\mathrm{N}$ with Dependent Variable $=1$ & 51 & 38 \\
\hline \multicolumn{3}{|l|}{ Dependent variable: $\Delta(L A / A)>0$} \\
\hline Stock return $_{t-1}$ & $\begin{array}{c}-0.435 \\
(-0.608)\end{array}$ & $\begin{array}{c}0.173 \\
(0.179)\end{array}$ \\
\hline Log likelihood & -73.88 & -43.70 \\
\hline $\mathrm{N}$ with Dependent Variable $=0$ & 43 & 28 \\
\hline $\mathrm{N}$ with Dependent Variable $=1$ & 71 & 36 \\
\hline \multicolumn{3}{|c|}{ Dependent variable: $\triangle(N P L / A)<0$} \\
\hline Stock return ${ }_{t-1}$ & $\begin{array}{l}1.880^{* * *} \\
(2.492)\end{array}$ & $\begin{array}{c}1.157 \\
(1.081)\end{array}$ \\
\hline Log likelihood & -62.51 & -36.38 \\
\hline $\mathrm{N}$ with Dependent Variable $=0$ & 31 & 20 \\
\hline $\mathrm{N}$ with Dependent Variable $=1$ & 83 & 44 \\
\hline
\end{tabular}

** denotes statistical significance at the $5 \%$ level

Furthermore, increasing, say Tier I capital would have the effect of further reducing the rate of return on stocks. The coefficient of returns in the liquidity equation is also not significant and indicates the difficulties and costs involved in changing the asset composition. So, reducing non-operating loans either by turning them over to asset management companies or writing them off remains the only management actions when shareholders experience negative stock returns. Although banks also improve their liquidity when shareholders have negative returns in the last period, this response is not significant.

We also estimate the market influence model for large and small bank subsamples to test for any differences in the responses to negative returns by different types of banks. We present the estimation results of the market influence model for the subsets of large and small banks in Table $6 .{ }^{13}$ Similar to the estimates for all banks, we find shareholder influence to only be effective for nonperforming loans of small banks. The effect on large banks is not significant.

\subsection{Robustness check}

Some banks have non-standard ownership structures in Turkey. ${ }^{14}$ The largest bank by asset size, İşbank, is partly owned by a political party and an employees' pension fund. Şekerbank is one-third owned by an employees' pension fund, one-third by a foreign company, and one-third is publicly traded. In another case, government is the largest shareholder in Vakıfbank. As a robustness check, we exclude these

\footnotetext{
${ }^{13}$ We did not report the results of the full models in the paper in order to save space. They are available on request.

${ }^{14}$ Section 1 discusses bank ownership by different types of institutions.
} 
Table 7 Fixed effect estimates of the monitoring and influence models excluding selected banks (İşbank, Vakıfbank and Şekerbank) with different ownership structure. ${ }^{\dagger}$ Negative stock returns are used in the influence model. t-statistics and z-statistics are in parentheses

\begin{tabular}{|c|c|c|c|c|}
\hline & \multirow{2}{*}{$\begin{array}{l}\text { Monitoring } \\
\text { model }\end{array}$} & \multicolumn{3}{|c|}{ Influence model } \\
\hline & & $\Delta(K / A)>0$ & $\Delta(L A / A)>0$ & $\Delta(N P L / A)<0$ \\
\hline Stock return ${ }^{\dagger}$ & $\begin{array}{c}-0.441 * * * \\
(-8.000)\end{array}$ & $\begin{array}{c}-0.394 \\
(-0.765)\end{array}$ & $\begin{array}{c}-1.156^{* *} \\
(-2.249)\end{array}$ & $\begin{array}{c}1.411 * * * \\
(2.737)\end{array}$ \\
\hline Nonperforming loans/assets & $\begin{array}{l}-1.531 \\
(-1.130)\end{array}$ & & & \\
\hline Capital/assets & $\begin{array}{l}1.792 * * \\
(2.104)\end{array}$ & & & \\
\hline Operational efficiency & $\begin{array}{c}0.355^{* * * *} \\
(4.044)\end{array}$ & & & \\
\hline Liquid assets/assets & $\begin{array}{c}1.179 * * * * \\
(6.748)\end{array}$ & & & \\
\hline Total deposits/assets & $\begin{array}{c}0.757 * * * \\
(2.654)\end{array}$ & & & \\
\hline Total trading volume & $\begin{array}{c}0.097 * * * \\
(4.298)\end{array}$ & & & \\
\hline GDP growth & $\begin{array}{c}-2.250 * * * \\
(-5.942)\end{array}$ & & & \\
\hline Market-to-Book & $\begin{array}{c}0.133 * * * \\
(6.861)\end{array}$ & $\begin{array}{c}0.217 * * \\
(1.841)\end{array}$ & $\begin{array}{c}-0.044 \\
(-0.393)\end{array}$ & $\begin{array}{c}-0.080 \\
(-0.626)\end{array}$ \\
\hline Assets (in logs) & & $\begin{array}{l}-0.030 \\
(-1.614)\end{array}$ & $\begin{array}{c}0.013 \\
(0.736)\end{array}$ & $\begin{array}{c}0.083 * * * \\
(4.114)\end{array}$ \\
\hline BRSA dummy & & $\begin{array}{c}0.393 \\
(1.185)\end{array}$ & $\begin{array}{c}-0.462 \\
(-1.491)\end{array}$ & $\begin{array}{c}-0.498 \\
(-1.389)\end{array}$ \\
\hline $\mathrm{N}$ & 279 & 256 & 271 & 271 \\
\hline
\end{tabular}

*** and ${ }^{* *}$ denote statistical significance at the $1 \%$ and $5 \%$ levels, respectively

three banks that might have shareholders with different motivations than stock value maximization and examine monitoring and influence with the remaining banks. As seen in the first column of Table 7 , the results do not change significantly from the previous results reported in Table 4. However, the capital-to-assets ratio becomes a significant factor in understanding the riskiness of a bank. Moreover, shareholders are able to influence the bank management to increase the liquidity level, which is the second line of action for managements in reducing risk. Once banks with state and quasi-state ownership are removed from the sample the evidence for shareholder influence becomes stronger. Therefore, we observe that shareholders' influence in privately-owned banks is more evident where objectives of the owners is consistent with value maximization. In these cases management is compelled to take more fundamental measures to improve return to shareholders.

\section{Concluding remarks}

We test for the existence of banks' market discipline differentiated by type of bank. Shareholder discipline manifests itself in the form of monitoring banks' risk as well as influencing banks' management actions to limit risk taking. 
Shareholder returns have a significant relation to bank efficiency and liquidity. Shareholders who invest in small banks as part of a portfolio are sensitive to risk factors such as bank efficiency and liquidity as well as other factors including trading volume and franchise value. While this is true for small banks, bank efficiency is not a key concern for shareholders in the case of large banks. However, excluding some banks where the dominant shareholders might be motivated by different rentseeking objectives improves the significance of capital ratio, bank efficiency, and liquidity.

Shareholders, observing increased bank risk, expect management measures to reduce risk to acceptable levels that results in the reallocation of the bank's assets. However, the bank incurs costs while reallocating funds from risky assets to less risky assets. So, bank management tries to change the composition of the assets at minimum cost. We find evidence that there is a strong relation between negative returns to shareholders and the decline in nonperforming loans. This relation implies that management initiates a less costly adjustment to the bank's asset structure by reducing exposure to nonperforming loans. Exclusion of special-interest banks further strengthens the influence of shareholders by adding the liquidity ratio as a significant factor that bank management attempts to adjust.

The period covered in the estimations includes two severe financial crises: one in 1997 that affected emerging financial markets and the crisis that occurred in Turkey in 2001. These two crises provide sufficient evidence of management measures to protect franchise value. After experiencing two major crises and a number of supervisory changes, the Turkish banking industry demonstrates evidence of shareholder market discipline. The dominance of large shareholders limits banks' risk-taking behavior, particularly that of small banks. This limitation implies that the problems faced by the Turkish banking industry in the past are related to monetary and supervisory policies pursued by the government (Ertugrul and Yeldan 2003).

While we demonstrate the extent of the shareholders' influence on management measures, it should be remembered that the results are based on a sample of banks from one country. However, existence of a range of ownership structures enables us to better understand the effectiveness of different ownership types on management's risk control. The robustness of the results can be further tested with a cross-country context. Finally, including characteristics of different forms of ownership explicitly in the model would provide a better understanding of the role of shareholders in the determination of the risk-taking behavior of bank managers.

\section{References}

Batesse GE, Coelli (1995) A model for technical inefficiency effects in a stochastic frontier production function for panel data. Empir Econ 20(2):325-332

Berger AN, Mester (1997) Inside the black box: what explains differences in the efficiencies of the financial institutions. J Bank Financ 21(7):895-947

Billet M, Garfinkel J, O'Neal E (1998) The cost of market versus regulatory discipline in banking. J Financ Econ 48(3):333-358

BIS (2003) Markets for bank subordinated debt and equity in Basel committee member countries. BIS Working Paper No. 12

Bliss RR, Flannery MJ (2002) Market discipline in the governance of U.S. bank holding companies: monitoring vs. influence. Eur Financ Rev 6(3):361-395

Cannata F, Quagliariello M (2005) The value of market information in banking supervision: evidence from Italy. J Financ Serv Res 27(2):139-162 
Caprio G, Honohan P (2004) Can the unsophisticated market provide discipline? World Bank Policy Research Working Paper No. 3364

Casu B, Molyneux P (2003) A comparative study of efficiency in European banking. Appl Econ 35(17):1865-1876

Cihak M, Maechler A, Schaeck K, Marie Stolz S (2011) Who disciplines bank managers? Rev Financ. doi:10.1093/rof/rfr010

Curry TJ, Fissel GS, Hanweck GA (2008) Equity market information, bank holding company risk and market discipline. J Bank Financ 32(5):807-819

Demsetz H (1983) The structure of ownership and the theory of the firm. J Law Econ 26(2):375-390

Demsetz H (1986) Corporate control, insider trading, and rates of return. Am Econ Rev 76(2): 313-316

Demsetz H, Lehn K (1985) The structure of corporate ownership: causes and consequences. J Polit Econ 93(6):1155-1177

Demsetz RS, Saidenberg MR, Strahan PE (1996) Banks with something to lose: the disciplinary role of franchise value. Econ Policy Rev Oct:1-14

Distinguin I, Rous P, Tarazi A (2006) Market discipline and use of stock market data to predict bank financial distress. J Financ Serv Res 30(2):151-176

Docking DS, Hirschey M, Jones E (1997) Information and contagion effects of bank loan-loss reserve announcements. J Financ Econ 43(2):219-239

Ertugrul A, Yeldan E (2003) On the structural weaknesses of the post-1999 Turkish disinflation program. In: Onis Z, Rubin B (eds) The Turkish economy in crisis. Frank Cass, London, pp 53-66

Flannery MJ (1998) Using market information in prudential bank supervision: a review of the U.S. empirical evidence. J Money Credit Bank 30(3):273-305

Flannery KJ (2001) The faces of 'market discipline'. J Financ Serv Res 20(23):107-119

Flannery MJ, Sorescu SM (1996) Market discipline in subordinated debenture yields: 1983-1991. J Financ 51(4):1347-1377

Flannery MJ, Kwan SH, Nimalendran M (2004) Market evidence on the opaqueness of banking firms' assets. J Financ Econ 71(3):419-460

Furlong FT, Williams R (2006) Financial market signals and banking supervision: are current practices consistent with research findings? FRBSF Econ Rev 17-29

Goyal VK (2005) Market discipline of bank risk: evidence from subordinated debt contracts. J Financ Intermed 14(3):318-350

Gropp R, Vesela K, Vulpes G (2006) Equity and bond market signals as leading indicators of bank fragility. J Money Credit Bank 38(2):399-428

Hall JR, King TB, Meyer AP, Vaughan MD (2002) What can bank supervisors learn from equity markets? A comparison of the factors affecting market-based risk measures and BOPEC scores? Federal Reserve Bank of St. Louis, Working Paper

Hacimahmutoglu S (2007) The problems of minority protection and their solutions within the legal framework in Turkish corporate governance. J Bank Reg 8:131-158

Hancock D, Kwast M (2001) Using subordinated debt to monitor bank holding companies: is it feasible? J Financ Serv Res 20(2-3):147-187

Haubrich J, Thomson JB (1998) Large shareholders and market discipline in a regulated industry: a clinical study of Mellon Bank. Federal Reserve Bank of Cleveland Working Paper No 9803

Himmelberg CP, Hubbard RG, Palia D (1999) Understanding the determinants of managerial ownership and the link between ownership and performance. J Financ Econ 53(3): 353-384

Jordan JS, Peek J, Rosengren ES (2000) The market reaction to the disclosure of supervisory actions: implications for bank transparency. J Financ Intermed 9(3):298-319

Keeley MC (2000) Deposit insurance, risk, and market power in banking. Amer Econ Rev 80(5):1183-1200

Krainer J, Lopez JA (2004) Incorporating equity market information into supervisory monitoring models. J Money Credit Bank 36(6):1043-1067

Kwan S (2002) The promise and limits of market discipline in banking. FRBSF Economic Letter, Federal Reserve Bank of San Francisco, Number 2002-36

Kwan S (2004) Testing the strong-form of market discipline: the effects of public market signals on bank risk. Federal Reserve Bank of San Francisco Working Paper 2004-19

Lane TD (1993) Market discipline. IMF Staff Pap 40(1):53-88

Morgan D, Stiroh K (2001) Market discipline of banks: the asset test. J Financ Serv Res 20(2): 195-208 
Nier E, Baumann U (2006) Market discipline, disclosure and moral hazard in banking. J Financ Intermed 15(3):332-361

Nikolova S (2003) Bank risk reflected in security prices: combining equity and debt market information to assess bank condition. Working Paper

Parrinoa R, Sias RW, Starks LT (2003) Voting with their feet: institutional ownership changes around forced CEO turnover. J Financ Econ 68(1):3-46

Shleifer A, Vishny RW (1986) Large shareholders and corporate control. J Polit Econ 94(3):461-488

Shleifer A, Vishny RW (1997) A survey of corporate governance. J Finance 52(2):737-783

Steinherr A, Tukel A, Ucer M (2004) The Turkish banking sector: challenges and outlook in transition to EU membership. European Investment Bank Working Paper No. 2004/02

Sunderesan SM (2001) Supervisors and market analysts: what should research be seeking? J Financ Serv Res 20(2):275-280

Wheelock DC, Wilson PW (2000) Why do banks disappear? The determinants of U.S. bank failures and acquisitions. Rev Econ Stat 82(1):127-138 